\title{
The diversity of abnormal hormone receptors in adrenal Cushing's syndrome allows novel pharmacological therapies
}

A. Lacroix, N. N'Diaye,

H. Mircescu, J. Tremblay and P. Hamet
Division of Endocrinology, Department of Medicine, Research Center, Hôtel-Dieu du Centre Hospitalier de I'Université de Montréal (CHUM), Montréal, Canada

\section{Correspondence \\ A. Lacroix \\ Division of Endocrinology \\ Research Center \\ Hôtel-Dieu du CHUM \\ 3850 St-U rbain street \\ Montréal, Q uébec \\ Canada $\mathrm{H} 2 \mathrm{~W}$ 1T8 \\ Fax: + 51-4-843-2715 \\ E-mail: andre.lacroix@ umontreal.ca \\ Presented at the First \\ International M eeting on Adrenal \\ Disease: Basic and Clinical \\ Aspects, Ribeirão Preto, SP, Brazil, \\ August 31-September 2, 1999.}

Research supported by the Medical Research Council of Canada (No. MA 10339).

Received December 20, 1999 Accepted March 22, 2000

\section{Abstract}

Recent studies from several groups have indicated that abnormal or ectopic expression and function of adrenal receptors for various hormones may regulate cortisol production in ACTH-independent hypercortisolism. Gastric inhibitory polypeptide (GIP)-dependent Cushing's syndrome has been described in patients with either unilateral adenoma or bilateral macronodular adrenal hyperplasia; this syndrome results from the large adrenal overexpression of the GIP receptor without any activating mutation. We have conducted a systematic in vivo evaluation of patients with adrenal Cushing's syndrome in order to identify the presence of abnormal hormone receptors. In macronodular adrenal hyperplasia, we have identified, in addition to GIP-dependent Cushing's syndrome, other patients in whom cortisol production was regulated abnormally by vasopressin, ß-adrenergic receptor agonists, $\mathrm{hCG} / \mathrm{LH}$, or serotonin $5 \mathrm{HT}-4$ receptor agonists. In patients with unilateral adrenal adenoma, the abnormal expression or function of GIP or vasopressin receptor has been found, but the presence of ectopic or abnormal hormone receptors appears to be less prevalent than in macronodular adrenal hyperplasia. The identification of the presence of an abnormal adrenal receptor offers the possibility of a new pharmacological approach to control hypercortisolism by suppressing the endogenous ligands or by using specific antagonists for the abnormal receptors.

\section{Introduction}

Cushing's syndrome results from the chronic exposure to excess amounts of glucocorticoids (1). Endogenous Cushing's syndrome is classically divided into two groups: hypercortisolism can be ACTH-dependent (80-85\%), resulting from an excess produc-

\section{Key words}

- Adrenal cortex

- Cortisol

- Cushing's syndrome

- Ectopic expression

- Hormone receptors 
pituitary (ectopic CRH syndrome). The second group of ACTH-independent Cushing's syndrome (15-20\%) results from excess secretion of cortisol by adrenocortical benign and malignant tumors or hyperplasia (1). Rare cases of ACTH-independent bilateral adrenal hyperplasia have also been reported and their pathophysiology is diverse. Primary pigmented nodular adrenocortical disease can be familial, associated with other tumors such as myxomas, schwannomas, pigmented cutaneous lesions and peripheral endocrine tumors (Carney's complex) and linked to unknown genes on chromosomes 2 and 17 (2). In McCune-Albright syndrome, activating mutations of $\mathrm{G}_{\mathrm{s} \alpha}$ in adrenal nodules induce constitutive steroidogenesis (3).

The mechanisms by which cortisol is produced in ACTH-independent adrenal Cushing's syndrome were previously unknown; studies by several groups have indicated that these "autonomous" cortisol-producing adrenal tumors may, in fact, be under the control of inappropriate, illicit or ectopic hormone receptors. This concept was proposed initially by Robert Ney and his collaborators in $1971(4,5)$. In studies on the role of adenylyl cyclase (AC) in mediating the effects of ACTH in adrenal steroidogenesis, only ACTH was capable of stimulating $\mathrm{AC}$ in normal cortex; however, in rat or human adrenal adenomas or cancers, these investigators demonstrated, in vitro, that AC was stimulated by hormones other than ACTH such as epinephrine, norepinephrine, thyroid stimulating hormone (TSH), luteinizing hormone ( $\mathrm{LH})$ and follicle stimulating hormone (FSH). Other in vitro studies (6-11) have further supported the functional coupling of several $\mathrm{G}$ protein-linked receptors to steroidogenesis in some human adrenocortical benign and malignant tumors (Table 1). Type I interleukin-1 receptor which is not a member of 7-transmembrane $G$ proteincoupled receptors was also found to be aberrantly expressed in an adenoma in which cortisol secretion was stimulated in vitro by interleukin-1 (12). The proposed concept of ectopic hormone receptors had been demonstrated in vitro only, and it was not clear whether these ectopic or illicit receptors were effectively functional and responsible for the clinical syndrome. The hypothesis found a clinical demonstration of its significance $i n$ vivo with the description of two cases of Cushing's syndrome modulated by an adrenal receptor for a gastrointestinal hormone called gastric inhibitory polypeptide or GIP $(13,14)$, thus presenting as food-dependent Cushing's syndrome. We will briefly review, in this article, the recent demonstration by several groups that cortisol production in adrenal Cushing's syndrome can result from the abnormal adrenocortical expression and function of a diversity of hormone receptors (Table 1).

\section{Material and Methods}

\section{In vivo clinical study protocols}

The protocol utilized to screen for potential ectopic adrenal hormone receptors has been described (15); it includes serial measurements at 30-60-min intervals for 2-3 h of plasma ACTH, cortisol and other steroids or hormones as indicated (aldosterone, free testosterone, dehydroepiandrosterone sulfate, and estradiol) during the course of the various tests performed after an overnight fast and in supine posture for at least one hour. The initial screening tests include a posture test performed during a 2-h supine position, followed by a 2-h ambulation period (evaluates potential modulation by angiotensin II, vasopressin, catecholamines, atrial natriuretic peptide (ANP), etc.); this is followed by a standard mixed meal (evaluates response of gastrointestinal hormones) and then by the administration of $250 \mu \mathrm{g}$ ACTH 1-24 iv which serves as a reference test. On another day, the administration of $100 \mu \mathrm{g}$ gonadotrophin releasing hormone $(\mathrm{GnRH}) i v$ (modulation by $\mathrm{FSH}, \mathrm{LH}$ and $\mathrm{GnRH}$ ) is followed 
by $200 \mu \mathrm{g}$ thyrotropin releasing hormone (TRH) iv (modulation by TSH, prolactin and TRH). The response to $1 \mathrm{mg}$ glucagon $i v, 10$ IU arginine-vasopressin (AVP) $\mathrm{im}$, and $10 \mathrm{mg}$ cisapride orally (a serotonin 5HT-4 receptor agonist) is determined sequentially on a third day. A change in plasma cortisol of less than $25 \%$ was arbitrarily defined as no response, a 25 to $49 \%$ change as a partial response and a change of $50 \%$ or greater as a positive response.

Following the initial screening tests, other tests can be performed to confirm the re- sponses or to elucidate which hormone is implicated. For example, if a stimulation of cortisol is found during upright posture, the respective contribution of elevations of vasopressin, catecholamines and angiotensin II needs to be distinguished. In the case of a concomitant absence of response to exogenous AVP, the role of angiotensin II is assessed by repeating the posture test after administration of an AT-1 receptor antagonist or by direct infusion of angiotensin II. If a catecholamine response is suspected, endogenous catecholamine stimulation is pro-

Table 1 - Abnormal hormone receptors in adrenocortical tumors.

AC: Adenylyl cyclase; GIPR: gastric inhibitory polypeptide receptor; AIMAH: ACTH-independent bilateral macronodular adrenal hyperplasia.

\begin{tabular}{|c|c|c|}
\hline $\begin{array}{l}\text { A) Demonstration limited to in vitro studies } \\
\text { Tissues }\end{array}$ & Ectopic receptors & References \\
\hline \multirow[t]{2}{*}{ Rat adrenal carcinoma 494} & AC stimulation by adrenalin, TSH, LH, FSH & 4 \\
\hline & ß-Adrenergic receptors & 6 \\
\hline $\begin{array}{l}\text { Human cortisol-secreting adrenal adenomas } \\
\text { and carcinomas }\end{array}$ & AC stimulation by TSH & 5 \\
\hline Human cortisol-secreting adrenal carcinomas & AC stimulation by $\mathrm{GH}, \mathrm{LH}$, and prolactin & 7 \\
\hline Human cortisol-producing adenomas & AC stimulation by $\mathrm{NE}, \mathrm{E}, \mathrm{TSH}$, and LH & 8 \\
\hline Human primary nodular hyperplasia & AC stimulation by glucagon & 8 \\
\hline Human cortisol-producing adenomas & ß-Adrenergic receptors & 9 \\
\hline Human cortisol-producing carcinomas & B-Adrenergic receptors & 10 \\
\hline Human cortisol-producing adenoma & Type I interleukin-1 receptor & 12 \\
\hline \multicolumn{3}{|l|}{ B) Demonstration by in vivo and in vitro studies } \\
\hline Tissues & Ectopic receptors & References \\
\hline Human cortisol-producing adenoma & $\begin{array}{l}\text { Food-dependent Cushing's syndrome; } \\
\text { AC stimulation by vasopressin (probably GIP) }\end{array}$ & 19 \\
\hline Human virilizing adenoma & $\begin{array}{l}\mathrm{LH} / \mathrm{hCG} \text { receptor in vivo and in vitro stimulation of } \\
\text { androgens by } \mathrm{hCG}\end{array}$ & 11 \\
\hline $\begin{array}{l}\text { GIP-dependent bilateral macronodular adrenal } \\
\text { hyperplasia }\end{array}$ & $\begin{array}{l}\text { Steroidogenesis stimulated by GIP; GIPR } \\
\text { overexpressed }\end{array}$ & $13,14,17,20,21,25$ \\
\hline $\begin{array}{l}\text { GIP-dependent adrenal adenomas and Cushing's } \\
\text { syndrome }\end{array}$ & $\begin{array}{l}\text { Steroidogenesis stimulated by GIP; GIPR } \\
\text { overexpressed }\end{array}$ & $20,22-25$ \\
\hline $\begin{array}{l}\text { Vasopressin responsive adrenal adenomas and } \\
\text { macronodular hyperplasia }\end{array}$ & $\begin{array}{l}\text { Steroidogenesis stimulated by LVP or AVP; } \\
\text { variable } V_{1} \text { vasopressin receptor eutopic expression }\end{array}$ & $18,26-30$ \\
\hline $\begin{array}{l}\text { Catecholamine-dependent AIMAH and Cushing's } \\
\text { syndrome }\end{array}$ & $\begin{array}{l}\text { Steroidogenesis stimulated by ß-adrenergic agonists } \\
\text { and inhibited by propranolol }\end{array}$ & 16,30 \\
\hline LH-dependent AIMAH and Cushing's syndrome & $\begin{array}{l}\text { Steroidogenesis stimulated by LH and } 5 \mathrm{HT}-4 \\
\text { receptor agonists; control of hypercortisolism with } \\
\text { leuprolide acetate }\end{array}$ & 33 \\
\hline
\end{tabular}


duced by an insulin-induced hypoglycemia, and, if positive, by an infusion of isoproterenol (16).

In case of a response to a mixed meal, the confirmation and identification of the gastrointestinal hormone implicated have prompted us to evaluate the effects of carbohydrates, proteins or lipids on cortisol secretion. The patients sequentially received, at 3$\mathrm{h}$ intervals, $75 \mathrm{~g}$ oral glucose, an isocaloric protein-rich meal or a lipid-rich meal $(13,17)$. Plasma levels of cortisol, ACTH, GIP, and insulin were determined at regular intervals during these tests. The absence of cortisol response to the $i v$ administration of $25 \mathrm{~g}$ of glucose or when $100 \mu \mathrm{g}$ of octreotide is administered $s c 60$ min prior to repeating the oral 75-g glucose challenge, confirms the role of a gastrointestinal hormone $(13,17)$. As only GIP and glucacon-like peptide-1 (GLP-1) respond well to oral glucose, lipids and partially to proteins, human GIP was infused at a rate of $0.6 \mu \mathrm{g} \mathrm{kg}^{-1} \mathrm{~min}^{-1}$ during the administration of $150 \mathrm{cc} / \mathrm{h}$ of $10 \%$ glucose and compared to the response to GLP1 infused at a rate of $0.75 \mathrm{pmol} \mathrm{kg}^{-1} \mathrm{~min}^{-1}$ also under $10 \%$ glucose $(13,17)$. Other protocols have been similarly conducted to identify the specific hormone implicated in the responses observed during the screening protocol $(15,16,18)$.

\section{In vitro studies of adrenocortical hormone receptor expression and function}

At the time of surgery, adrenal tissues are rapidly collected and frozen either in liquid nitrogen or isopentane to conduct further studies of ligand binding or AC activity on cell membrane preparations. In addition, the presence and molecular characterization of the receptors have been conducted using RT-PCR amplification, DNA sequencing or in situ hybridization. Studies were also conducted on adrenal cells freshly dispersed, in perifusion or in primary culture to characterize the response of second messengers and of steroidogenesis to the various hormones and ligands of the abnormal receptors.

\section{Results and Discussion}

\section{GIP-dependent Cushing's syndrome}

Hamet et al. (19) were the first to identify food-dependent cortisol production in a patient with a unilateral cortisol-secreting adrenal adenoma and periodic hormonogenesis. Plasma fasting cortisol was curiously low in the morning and increased following food ingestion. Two patients with bilateral ACTH-independent macronodular adrenal hyperplasia (AIMAH) and food-dependent cortisol production were studied in detail and allowed to clarify the pathophysiology of this syndrome $(13,14)$. The suspicion that cortisol production was regulated by a gastrointestinal hormone came from the observation that it was stimulated by oral administration of glucose, lipid-rich or protein-rich meals, but not by intravenous glucose. In addition, somatostatin pretreatment inhibited the stimulatory effect of oral glucose. Plasma cortisol levels were correlated with plasma GIP levels following the ingestion of various meals. The in vivo infusion of physiological concentrations of GIP was shown to stimulate cortisol production in the patients, but not in normal controls. The presence of GIP receptors in the adrenal tissues was supported by the adrenal imaging following the injection of [ $\left.{ }^{123} \mathrm{I}\right]-\mathrm{GIP}$ in vivo (13). Incubation of the dispersed adrenal cells, in vitro, confirmed the GIP-mediated cortisol secretion in the patient's cells, whereas no cortisol response to GIP was found in adult or fetal normal adrenal cells or in other cortisol- or aldosterone-secreting adenomas (13). GIP-dependent Cushing's syndrome has now been reported in several other patients with AIMAH $(17,20,21)$ or with a unilateral adenoma $(20,22-24)$ and this is summarized in Table 1B. In one patient with GIP-dependent AIMAH, the plasma ACTH and cortisol re- 
sponse to CRH was still preserved, presumably because the intermittent food-dependent stimulation of cortisol had not yet completely suppressed the hypothalamic-pituitary-adrenal axis (21). Recent molecular analyses indicate that the pathological adrenal tissues of the patients with GIP-dependent Cushing's syndrome highly overexpressed GIP receptors which were not mutated (17,20-25); a very weak expression was found in the normal human adrenals (25), but was not efficiently coupled to steroidogenesis. The overexpression of GIP receptors was found to be present even in the early stages of adrenal hyperplasia (17). Chabre et al. (23) also demonstrated a stimulation of thymidine incorporation by GIP in adrenal cells from GIP-dependent Cushing's syndrome but not in normal cells. A pharmacological blockade of hypercortisolism with octreotide, which inhibits postprandial release of GIP, was attempted as an alternative to surgery in a few patients $(14,21,22)$. During the first months, the therapy led to clinical and biological improvement, but the longterm treatment proved to be ineffective. It is presumed that the long-term inefficiency of octreotide is secondary to downregulation of somatostatin receptors in GIP-secreting intestinal cells. Thus, adrenalectomy remains the long-term treatment required for this syndrome.

\section{Vasopressin-responsive Cushing's syndrome}

Abnormal adrenal stimulation of cortisol secretion in response to exogenous arginine or lysine-vasopressin administration has recently been described in ACTH-independent Cushing's syndrome secondary to unilateral adrenal adenomas, carcinomas or AIMAH (18,26-29). In a retrospective study of 26 cortisol-secreting tumors, Arnaldi et al. (29) found such a response in $27 \%$ of cases. A patient with Cushing's syndrome and AIMAH also presented with the unusual association of orthostatic hypotension (18).
Exogenous AVP, but not desmopressin, triggered a large in vivo cortisol response in this patient. During upright posture and hypotension, cortisol and aldosterone secretion increased despite the suppression of ACTH and renin levels. AVP, which normally increases during upright posture and even further in orthostatic hypotension, remained below the limit of detection in this patient until the correction of hypercortisolism. Under dexamethasone suppression, plasma cortisol, aldosterone and androgens were increased by exogenous AVP in this patient, but not in controls. Cells freshly dispersed from the adrenal hyperplasia displayed a higher cortisol response to AVP than normal adrenal cells; the cortisol response was mediated by $\mathrm{V}_{1}$-AVP receptors. This constitutes an example of increased expression or response of a receptor which is normally present in the adrenal (eutopic receptor), but which does not normally mediate a large glucocorticoid production. $\mathrm{V}_{1}$-AVP receptors were found to be expressed either at normal (18) or increased levels (26-29) in the adrenal tissues which presented an exaggerated response to vasopressin. In cases where the receptor is quantitatively normal, activating mutations of the receptor or its effector system could be present, but have not been characterized to date.

Interestingly, the alteration in the $\mathrm{V}_{1^{-}}$ receptor-effector system was not limited to the adrenal tissues in the patient with AIMAH and orthostatic hypotension, as it was shown that there was also an abnormal prolonged vascular vasoconstrictive response to AVP compared to arterioles of normal subjects (18). The persistence of a decreased stimulation of plasma vasopressin and endothelin levels during postural hypotension several months after the correction of hypercortisolism also raises the possibility of an exaggerated $V_{1}$-AVP receptor signal at the hypothalamic level in this patient. The causal relationship between the abnormal $\mathrm{V}_{1}$-AVP responses and the postural hypotension re- 
mains uncertain.

The demonstration of an exaggerated cortisol response to pharmacological levels of exogenous vasopressin does not constitute a direct demonstration that fluctuations of endogenous levels of AVP are the main regulator of steroidogenesis in those patients. This was illustrated in a patient with AIMAH who was shown to increase plasma cortisol in response to upright posture and exogenous AVP (16); however, the modulation of endogenous levels of AVP by water dilution or hypertonic saline infusion did not modify plasma cortisol levels. In addition, the administration of a $\mathrm{V}_{1}$-AVP antagonist, in vivo, was able to inhibit the response of cortisol to exogenous AVP but not to upright posture. We have studied one woman with AIMAH whose cortisol was stimulated by upright posture and exogenous AVP, but not by dDAVP. In this patient, plasma cortisol was also inhibited by a water load and increased by hypertonic saline infusion (30).

\section{Catecholamine-dependent Cushing's syndrome}

The adrenal expression of ectopic $\beta$-adrenergic receptors ( $\beta$-ARs) was also recently identified in a man with AIMAH and Cushing's syndrome (16). The ACTH-independent overproduction of cortisol and aldosterone occurred during elevations of endogenous levels of catecholamines (upright posture, insulin-induced hypoglycemia, and stress test). Plasma cortisol elevation during upright posture was blunted following pretreatment with the $\beta$-adrenergic antagonist propranolol. Infusion of isoproterenol stimulated cortisol and aldosterone secretion in the patient but not in normal subjects in whom ACTH had been suppressed by dexamethasone. High affinity binding sites compatible with $\beta_{1}$-AR or $\beta_{2}$-AR were found in the adrenal tissue of the patient but not in controls. They were efficiently coupled to steroidogenesis, as shown by the stimulation of AC with isoproterenol in vitro and catecholamine-induced steroidogenesis in vivo. Further studies will be needed to properly characterize the receptor subtype which is expressed in the adrenal hyperplastic tissues and to determine whether it is mutated or not.

Long-term treatment of the patient with propranolol was efficient in completely restoring normal cortisol production. This constitutes the first example of a long-term pharmacological blockade of an ectopic adrenal hormone receptor. Interestingly, the control of hypercortisolism was followed by a decreased requirement of $\beta$-blocker doses. Glucocorticoids are known to stimulate $\beta_{2}$-AR transcription (31) via glucocorticoid response elements that are located in the promoters of the target genes (32). The normalization of cortisol level may have decreased B-AR density, which would explain the lower requirement for the antagonist. The propranolol therapy did not decrease the size of the remaining adrenal; however, only the minimal dose of propranolol necessary to maintain normal cortisol production without blocking the receptors completely was administered. Another woman with AIMAH was found to present abnormal responses to upright posture, exogenous AVP and insulin-induced hypoglycemia. Further studies indicated that cortisol production was modulated by infusion of isoproterenol and by fluctuations of endogenous levels of vasopressin, suggesting the presence of both $\mathrm{V}_{1}$-AVP and B-AR receptors (30).

\section{Cushing's syndrome secondary to other abnormal adrenal hormone receptors}

A woman with AIMAH reported a history of transient Cushing's syndrome during pregnancy, while chronic hypercortisolism became manifest only after menopause. Cortisol production was increased by the administration of $\mathrm{GnRH}$, human chorionic gonad- 
otropin (hCG) and LH (33). An abnormal stimulation of cortisol production was also produced by oral administration of cisapride and metoclopramide which are serotonin (5HT-4) receptor agonists (34). Suppression of endogenous levels of LH with leuprolide acetate was able to normalize cortisol production.

We have now systematically evaluated 19 consecutive patients with adrenal Cushing's syndrome secondary to bilateral macronodular adrenal hyperplasia $(\mathrm{N}=6)$, micronodular adrenal dysplasia $(\mathrm{N}=1)$, unilateral adenoma $(\mathrm{N}=11)$, or carcinoma $(\mathrm{N}=1)$ for evidence of an abnormal hormone receptor (30). All six patients with AIMAH had a positive response to at least one test in addition to ACTH 1-24: two patients to the mixed meal (GIP-dependent), one patient to $\mathrm{GnRH}$ (LH receptor) and cisapride (5HT-4 receptor), and three patients to the upright posture and to vasopressin ( 1 ß-AR, $1 \mathrm{~V}_{1}$-AVP receptor, 1 B-AR and $V_{1}-A V P$ receptor). Among patients with unilateral adenoma, only one had a positive response to upright posture, while two partial responses either to the mixed meal or to vasopressin were also noted, but were not further characterized. In the patients with adrenocortical carcinoma or micronodular adrenal dysplasia, plasma cortisol was not modified by any of the tests. Our initial experience suggests that the adrenal expression of various ectopic or abnormal hormone receptors is frequently implicated in the pathophysiology of bilateral macronodular adrenal hyperplasia, but less frequently in the pathophysiology of unilateral adenoma.

Taken together, the results of the in vitro and in vivo studies indicate that a wide diversity of abnormal adrenal hormone receptors can be present in Cushing's syndrome. It is likely that any receptor that could become efficiently coupled to G proteins and to steroidogenesis will eventually be identified.
Table 2 - Potential pharmacological therapy for abnormal hormone receptors in adrenocortical tumors.

\begin{tabular}{ll} 
Abnormal receptor & Therapy \\
\hline GIP receptor & Somatostatin or GIPR antagonist \\
B-Adrenergic receptor & B-Blockers \\
TSH receptor & L-Thyroxine \\
V 1 -AVP receptor & V 1 -AVP receptor antagonist \\
Angiotensin II receptor & AT-1 receptor antagonist \\
LH receptor & GnRH analogs \\
5HT-4 receptor & 5HT-4 receptor antagonists
\end{tabular}

\section{Novel pharmacological therapies of adrenal Cushing's syndrome}

The identification of ectopic or abnormal adrenal hormone receptors in cortisol-secreting hyperplasia or tumors permits the use of specific pharmacological therapies as alternatives to adrenalectomy. This has now been illustrated by the short-term improvement of hypercortisolism with triiodothyronine in a TSH-dependent adrenal cortisolsecreting adenoma (5), with octreotide in GIP-dependent Cushing's syndrome (14,21, 22 ), and by the long-term control of ectopic ß-AR by propranolol (16) and of LH receptor by leuprolide acetate (33). Further studies will probably identify a larger diversity of hormone receptor abnormalities and should eventually allow the use of new pharmacological tools to either inhibit the production of the endogenous ligands or block the receptors with appropriate specific antagonists (Table 2).

\section{Acknowledgments}

We wish to acknowledge Drs. E. Bolté, J.-M. Boutin, W. de Herder, R.M. Touyz, L.Y. Deng, R. Larivière, J.R. Cusson, E.L. Schiffrin, G. Rousseau, and M. Bouvier, the patients and their referring physicians, the CHUM Endocrine Division members, nurses, laboratory technicians and secretaries for their contributions to this work. 


\section{References}

1. Nieman L \& Cutler J r GB (1995). Cushing's syndrome. In: De Groot LJ (Editor), Endocrinology. Saunders, Philadelphia, 1741-1770.

2. Stratakis CA, Carney J A, Lin J P, Papanicolaou DA, Karl M, Kastner DL, Pras E \& Chrousos GP (1996). Carney complex, a familial multiple neoplasia and lentiginosis syndrome. Analysis of 11 kindreds and linkage to the short arm of chromosome 2. J ournal of Clinical Investigation, 97: 699-705.

3. Weinstein LS, Shenker A, Gejman PV, Merino MJ, Friedman E \& Spiegel AM (1991). Activating mutations of the stimulatory $\mathrm{G}$ protein in the McCune Albright syndrome. New England J ournal of Medicine, 325: 1688-1695.

4. Schorr I, Rathman P, Saxena BB \& Ney RL (1971). Multiple specific hormone receptors in the adenylate cyclase of an adrenocortical carcinoma. J ournal of Biological Chemistry, 246: 5806-5811.

5. Hingshaw HT \& Ney RL (1974). Abnormal control in the neoplastic adrenal cortex. In: McKerns KW (Editor), Hormones and Cancer. Academic Press, New York, 309327.

6. Williams LT, Gore TB \& Lefkowitz RJ (1977). Ectopic ß-adrenergic receptor binding sites. J ournal of Clinical Investigation, 59: 319-324.

7. Millington DS, Golder MP, Cowley T, London D, Roberts H, Butt WR \& Griffiths K (1976). In vitro synthesis of steroids by a feminising adrenocortical carcinoma: effect of prolactin and other protein hormones. Acta Endocrinologica, 82: 561571.

8. Matsukura S, Kakita T \& Sueko S (1980). Multiple hormone receptors in the adenylate cyclase of human adrenocortical tumors. Cancer Research, 40: 3768-3771.

9. Hirata $Y$, Uchihashi $M$, Sueko $S$, Matsukura S \& Fujita T (1981). Presence of ectopic $ß$-adrenergic receptors on human adrenocortical cortisol producing adenomas. J ournal of Clinical Endocrinology and Metabolism, 53: 953-957.

10. Katz MS, Kelly TM, Dax EM, Pineyro MA, Partilla J S \& Gregerman RI (1985). Ectopic ß-adrenergic receptors coupled to adenylate cyclase in human adrenocortical carcinomas. J ournal of Clinical Endocrinology and Metabolism, 60: 900-909.

11. Leinonen $P$, Ranta $T$, Siegberg $R$, Pelkonen R, Heikkila T \& Kahri A (1991). Testosterone-secreting virilizing adrenal adenoma with human chorionic gonado- trophin receptors and 21-hydroxylase deficiency. Clinical Endocrinology, 34: 3135.

12. Willenberg HS, Stratakis CA, Marx C, Erhart-Bornstein M, Chrousos GP \& Bornstein SR (1998). Aberrant interleukin1 receptors in a cortisol-secreting adrenal adenoma causing Cushing's syndrome. New England J ournal of Medicine, 339: 27-31.

13. Lacroix A, Bolté E, Tremblay J, Dupre J, Poitras P, Fournier H, Garon J, Garrel D, Bayard F, Taillefer R \& Hamet P (1992). Gastric inhibitory polypeptide-dependent cortisol hypersecretion: a new cause of Cushing's syndrome. New England J ournal of Medicine, 327: 974-980.

14. Reznik Y, Allali-Zerah V, Chayvialle JA, Leroyer R, Leymarie P, Travert $G$, Lebrethon MC, Budi I, Baillere AM \& Mahoudeau J (1992). Food-dependent Cushing's syndrome mediated by aberrant adrenal sensitivity to gastric inhibitory polypeptide. New England J ournal of Medicine, 327: 981-986.

15. Lacroix A, Mircescu H \& Hamet P (1999). Clinical evaluation of the presence of abnormal hormone receptors in adrenal Cushing's syndrome. The Endocrinologist, 9: 9-15.

16. Lacroix A, Tremblay J, Rousseau G, Bouvier M \& Hamet P (1997). Propranolol therapy for ectopic ß-adrenergic receptors in adrenal Cushing's syndrome. New England J ournal of Medicine, 337: 14291434.

17. N'Diaye N, Hamet P, Tremblay J, Boutin J -M, Gaboury L \& Lacroix A (1999). Asynchronous development of bilateral nodular adrenal hyperplasia in GIP-dependent Cushing's syndrome. J ournal of Clinical Endocrinology and M etabolism, 84: 26162622.

18. Lacroix A, Tremblay J, Touyz RM, Deng LD, Lariviere R, Cusson J R, Schiffrin EL \& Hamet P (1997). Abnormal adrenal and vascular responses to vasopressin mediated by a $V_{1}$-vasopressin receptor in a patient with adrenocorticotropin-independent macronodular adrenal hyperplasia, Cushing's syndrome and orthostatic hypotension. J ournal of Clinical Endocrinology and Metabolism, 82: 2414-2422.

19. Hamet $P$, Larochelle $P$, Franks $D J$, Cartier $P \&$ Bolté E (1987). Cushing's syndrome with food-dependent periodic hormonogenesis. Clinical and Investigative Medicine, 10: 530-533.

20. Lebrethon MC, Avallet O, Reznik $Y$,
Archambaud F, Combes J, Usdin TB, Narboni G, Mahoudeau J \& Saez J M (1998). Food-dependent Cushing's syndrome: characterization and functional role of gastric inhibitory polypeptide receptor in the adrenals of three patients. J ournal of Clinical Endocrinology and Metabolism, 83: 4514-4519.

21. Croughs JMR, Zelissen MJ P, Van Vroonhoven J MVT, Hofland LJ , N'Diaye N, Lacroix A \& De Herder W (2000). GIPdependent adrenal Cushing's syndrome with incomplete suppression of corticotropin. Clinical Endocrinology, 52: 235240.

22. De Herder WW, Hofland LJ , Usdin TB, De J ong $\mathrm{FH}$, Uitterlinden $\mathrm{P}$, Van Koetsveld $\mathrm{P}$, Mezey $\mathrm{E}$, Bonner TI, Bonjer HJ \& Lamberts SW (1996). Food-dependent Cushing's syndrome resulting from abundant expression of gastric inhibitory polypeptide receptors in adrenal adenoma cells. J oumal of Clinical Endocrinology and Metabolism, 81: 3168-3172.

23. Chabre $O$, Liakos $P$, Vivier J, Chaffanjon P, Labat-M oleur F, Martinie M, Bottari SP, Bachelot I, Chambaz EM, Defaye G \& Feige J J (1998). Cushing's syndrome due to a gastric inhibitory polypeptide-dependent adrenal adenoma: insights into hormonal control of adrenocortical tumorigenesis. J ournal of Clinical Endocrinology and Metabolism, 83: 3134-3143.

24. Luton JP, Bertherat J, Kuhn J M \& Bertagna X (1998). Aberrant expression of GIP (gastric inhibitory polypeptide) receptor in an adrenal cortical adenoma responsible for a case of food-dependent Cushing's syndrome. Bulletin de l'Academie Nationale de Medecine, 182: 18391850.

25. N'Diaye N, Tremblay J, de Herder WW, Hamet P \& Lacroix A (1999). Adrenal overexpression of gastric inhibitory polypeptide receptor underlies food-dependent Cushing's syndrome. J ournal of Clinical Endocrinology and Metabolism, 83: 27812785.

26. Perraudin V, Delarue C, De Keyzer $Y$, Bertagna X, Kuhn J M, Contesse V, Clauser E \& Vaudry H (1995). Vasopressinresponsive adrenocortical tumor in a mild Cushing's syndrome: in vivo and in vitro studies. J ournal of Clinical Endocrinology and Metabolism, 80: 2661-2667.

27. Horiba $N$, Suda $T$, Aiba $M$, Naruse $M$ Nomura K, Imamura $M$ \& Demura $H$ (1995). Lysine vasopressin stimulation of cortisol secretion in patients with adreno- 
corticotropin-independent macronodular adrenal hyperplasia. J ournal of Clinical Endocrinology and Metabolism, 80: 23362341.

28. Ida $\mathrm{K}$, Kaji $\mathrm{H}$, Matsumoto $\mathrm{H}$, Okimura $\mathrm{Y}$, Abe $\mathrm{H}$, Fujisawa M, Kamidono $\mathrm{S} \&$ Chihara K (1997). Adrenocorticotrophin-independent macronodular adrenal hyperplasia in a patient with lysine vasopressin responsiveness but insensitivity to gastric inhibitory polypeptide. Clinical Endocrinology, 47: 739-745.

29. Arnaldi G, Gasc J M, De Keyzer Y, RaffinSanson ML, Perraudin V, Kuhn J M, RauxDemay MC, Luton JP, Clauser E \& Bertagna X (1998). Variable expression of the V1 vasopressin receptor modulates the phenotypic response of steroid-se- creting adrenocortical tumors. J ournal of Clinical Endocrinology and Metabolism, 83: 2029-2035.

30. Mircescu H, J ilwan J , Hamet P \& Lacroix A (1998). Systematic clinical screening for abnormal hormone receptors in adrenal Cushing's syndrome. Proceedings of the 80th Annual Meeting of the Endocrine Society. New Orleans, LA. The Endocrine Society Press, Bethesda, MD. Abstract OR21-2, 80.

31. Maki J C, Nishikawa M \& Barnes PJ (1995). Glucocorticoids increase beta2-adrenergic receptor transcription in human lung. American J ournal of Physiology, 268: L41-L46.

32. Malbon CC \& HadockJ R (1988). Evidence that glucocorticoid response elements in the $5^{\prime}$-noncoding region of the hamster $B_{2}$-adrenergic receptor gene are obligate for glucocorticoid regulation of receptor mRNA levels. Biochemical and Biophysical Research Communications, 154: 676681.

33. Lacroix A, Hamet $P$ \& Boutin J M (1999). Leuprolide acetate therapy in luteinizing hormone-dependent Cushing's syndrome. New England J oumal of Medicine, 341: 1577-1581.

34. Lefebvre $\mathrm{H}$, Contesse $\mathrm{V}$, Delarue $\mathrm{C}$, Vaudry K \& Kuhn J M (1998). Serotonergic regulation of adrenocortical function. Hormone and Metabolic Research, 30: 398403. 